\title{
The Prevalence of Fibromyalgia in Patients with Restless Legs Syndrome
}

\author{
Huzursuz Bacaklar Sendromlu Hastalarda Fibromiyalji Görülme Sıklı̆̆ı
}

Nesrin Helvacı Yılmaz¹, Emir Cantürk², Özge Arıcı Düz1 ${ }^{1}$, Bilge Parlakoğlu³ ${ }^{3}$ Burcu Polat ${ }^{1}$, Engin Çakar ${ }^{4}$, Sema Demirci'1, Ahmet Mithat Tavlı1, Didem Taşkın¹, Ayşe Pınar Doğru³, Lütfü Hanoğlu1 ${ }^{1}$, Fahriye Feriha Özer ${ }^{1}$

1 İstanbul Medipol University Faculty of Medicine, Department of Neurology, İstanbul, Turkey

2istanbul Medipol University Faculty of Medicine, Department of Cardiology\&Vascular, İstanbul, Turkey

3istanbul Medipol University Faculty of Medicine, Department of Psychiatry, İstanbul, Turkey

4istanbul Medipol University Faculty of Medicine, Department of Physical Therapy and Rehabilitation, İstanbul, Turkey

\section{Summary}

Objective: To determine the prevalence of fibromyalgia (FM) in patients with Restless legs syndrome (RLS), and to evaluate the relationship of FM and the scales of quality of life.

Materials and Methods: Thirty patients aged between 18-65 years (20 females, 10 males) with RLS and 30 healthy control subjects (17 female, 13 male) participated in our study. The patients were assessed using the the RLS Severity Rating Scale. The Pittsburg Sleep Quality Index (PSQI), Beck Depression Inventory, Beck Anxiety Questionnaire, and Quality of Life Short form-36 (SF-36) were given to both the patient and control group. The American College of Rheumatology criteria were used to diagnose FM.

Results: The average age of the patients was $44.73 \pm 11.23$ years, the average age of the control group was $46.00 \pm 12.23$ years. The prevalence of FM was $36.7 \%$ in the patient group and $6.7 \%$ in the control group $(\mathrm{p}=0.01)$. PSQI, depression and anxiety scores were significantly worse in the patient group ( $\mathrm{p}=0.0001 ; \mathrm{p}=0.004$; $\mathrm{p}=0.000)$. The patients with RLS had higher scores of mental health, social functioning, pain, and general perception of SF-36, and scale for the evaluation of quality of life $(\mathrm{p}=0.004 ; \mathrm{p}=0.023 ; \mathrm{p}<0.001 ; \mathrm{p}=0.001 ; \mathrm{p}=0.13)$; the scores for physical and emotional limitations did not differ between the patient and the control group. However, if a patient with RLS had additional FM symptoms, the general perception scores of the body were worse ( $\mathrm{p}=0.029)$. When we compared the scores of the patients with both RLS and FM with the healthy group, the anxiety scores were the most increased (three times).

Conclusion: The prevelance of FM was frequent (36.67\%) in patients with moderate and severe RLS. RLS impairs quality of life. However, coexistence of the two diseases only worsened patients' assessments of their own health score, and affected their anxiety scores the most.

Keywords: Fibromyalgia, Restless legs syndrome, Short form-36

Öz

Amaç: Çalışmamızın amacı Huzursuz bacaklar sendromlu (HBS) hastalarda fibromiyalji (FM) sıklığını belirlemek, yaşam kalitesi ölçekleri ve FM arasındaki ilişkiyi de ğerlendirmektir.

Gereç ve Yöntem: Çalışmamıza 18-65 yaş arasında HBS tanısı almış 30 hasta (20 kadın, 10 erkek) ve 30 sağlıklı kontrol (17 kadın, 13 erkek) katıldı. Hasta grubuna HBS Ağırlık Derecesi Ölçeği uygulanırken, hem hasta hem de kontrol grubuna Pittsburg Uyku Kalitesi İndeksi (PUKİ), Beck Depresyon Ölçeği, Beck Anksiyete Ölçeği ve Yaşam Kalitesi Kısa form-36 (KF-36) verildi. FM tanısı için Romatoloji Amerikan Koleji tarafından düzenlenen kriterler kullanılı.

Address for Correspondence/Yazışma Adresi: Nesrin Helvacı Yılmaz MD, İstanbul Medipol University Faculty of Medicine, Department of Neurology, İstanbul, Turkey Phone: +90 5326851390 E-mail: drnesrin76@gmail.com

Received/Geliş Tarihi: 13.03.2016 Accepted/Kabul Tarihi: 04.09.2016

${ }^{\circ}$ Copyright 2016 by Turkish Neurological Society

Turkish Journal of Neurology published by Galenos Yayinevi 


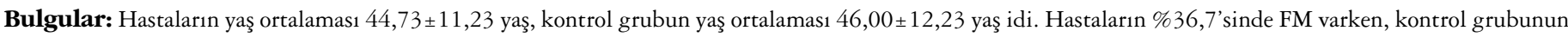
$\% 6,7$ 'sinde vardı $(\mathrm{p}=0,01)$. Hastaların PUKİ, depresyon ve anksiyete skorları anlamlı olarak daha kötüydü $(\mathrm{p}=0,0001 ; \mathrm{p}=0,004 ; \mathrm{p}=0,000)$. Yaşam kalitesini değerlendirme ölçeğine (KF-36) göre ise HBS’si olanlarda enerji, ruhsal sağlık, sosyal fonksiyon, ağrı ve genel alg1 puanları anlamlı olarak daha yüksekken $(\mathrm{p}=0,004 ; \mathrm{p}=0,023, \mathrm{p}=0,0001 ; \mathrm{p}=0,001 ; \mathrm{p}=0,13)$, fiziksel ve emosyonel kisıtllik puanları arasinda kontrol grubu ile fark saptanmadi. Ancak HBS olanlarda ek olarak FM varlığı sadece vücut genel alg1 değerinde kötüleşmeye neden olmaktaydı $(\mathrm{p}=0,029)$. HBS ve FM bulguları olan hastalar hiçbir hastalığı olmayan grupla karşılaştırılınca en çok anksiyete puanlarında (üç kat) artma olduğu tespit edildi.

Sonuç: Orta ve şiddetli HBS'li hastalarda FM sıktır (\%36,67). HBS yaşam kalitesini bozmaktadır. Ancak iki hastalığın birlikteliği sadece hastaların kendi sağlıklarını değerlendirme skorlarını kötüleştirmekte ve en çok anksiyete skorlarını olumsuz etkilemektedir.

Anahtar Kelimeler: Fibromiyalji, Huzursuz bacak sendromu, Kısa-form-36

\section{Introduction}

Restless legs syndrome (RLS) is characterized by an irresistible need to move the legs. It appears when the patient is sitting or lying down, most often in the evening or at night (1). About $55 \%$ of patients describe their symptoms as painful and this condition was attributed to dysfunction of the dopaminergic system, which is responsible for the modulation of pain $(2,3)$. Patients experience problems in central pain-modulatory processes in the long term, especially in dopaminergic and opioidergic descending pain inhibitory pathways (4). In a study conducted in young patients with RLS, shoulder and upper extremity pains were also common in addition to lower extremity pains (5). It was shown that patients with RLS, either treated or not, received significantly worse scores from Short form-36 (SF-36) health survey pain scale compared with the control group (4). The quality of life is low, and depressive symptoms and anxiety disorders are more common in patients with pain because of the more severe symptoms (6).

RLS is associated with many chronic pain syndromes. RLS is more frequent in patients with migraine, polyneuropathy, rheumatoid arthritis, and fibromyalgia (FM) (7). For the first time, RLS and leg cramps were reported more frequent in patients with FM in a study by Yunus and Aldag (8). The incidence of RLS in patients with FM was reported as $64 \%$ in later studies and this was 10 times higher than in controls $(9,10)$. The demonstration of the efficacy of dopaminergic drugs in the treatment of both diseases has brought about the theory that they share the same pathogenesis (11).

In this study, we aimed to determine the frequency of FM in patients with RLS who were admitted to our neurology outpatient clinic, and to evaluate the relationship between quality of life scales and FM.

\section{Materials and Methods}

Thirty patients with RLS (primary/secondary distinction was not made) aged 18-65 years who were diagnosed according to the International RLS Study Group criteria and had normal neurologic examination findings, and 30 healthy controls participated in this study. The exclusion criteria were as follows: pregnancy, antidepressant use in the last week, and neurologic diseases such as epilepsy, Alzheimer's disease, Parkinson's disease, and multiple sclerosis. Patients were questioned about the use of dopamine agonists. The control group consisted of relatives of physicians and healthcare personnel who work in the neurology outpatient clinic, and graduate students. Neurologic examinations of the healthy controls were normal and they had no RLS symptoms.

The study was initiated following approval from the ethics committee and written consent was obtained from all patients. The "RLS Rating Scale" was administered to the patient group (12). This scale consisted of ten items and the total score was calculated by scoring each question from 0 to 4 . Each question was graded from no impact (score 0) to very severe impact (score 4). The overall score ranged from 0 to 40 points; $1-10$ points being mild, 11-20 points moderate, 21-30 points severe, and 31-40 points very severe.

The Pittsburgh Sleep Quality Index (PSQI), Beck Depression Inventory (BDI), Beck Anxiety Inventory (BAI) and SF-36 were administered to both the patient and control groups $(13,14,15,16)$. The Turkish versions of BDI, BAI, PSQI, and SF-36 have been found highly reliable and valid $(17,18,19,20)$.

The SF-36 was used to evaluate quality of life. This form evaluates the eight sections of health (physical functioning, physical role functioning, emotional role functioning, social role functioning, mental health, vitality, bodily pain, and general health perceptions) in 36 items. The scale provides separate scores for each subscale and total scores range from 0-100. A score of zero is equivalent to maximum disability and a score of 100 is equivalent to no disability.

The American College of Rheumatology 2010 criteria were used for the diagnosis of FM (Table 1) (21). The presence/absence of FM was questioned in the patient and control groups.

\section{Statistical Analysis}

Descriptive statistical methods (mean, standard deviation, minimum, maximum) were used for data analysis.

Regarding differences, t-test was used for normal distribution and the Mann Whitney-u test was used for non-normal distribution. Chi-square and Fisher's exact tests were used for fractional data. The effects of variables were assessed using multinomial logistic regression analysis and Spearman's correlation analysis. The findings were evaluated at a confidence interval of $95 \%$ and significance level of $5 \%$. SPSS version 10.0 was used.

\section{Results}

The data and statistical values of the patient and control groups are presented in three tables (Table 2, 3, 4).

Among all variables, the presence of FM in the patient group was found as the only risk factor to statistically significantly increase "general health perceptions" scale 1.02 times. For the 
control group, none of the variables were found as statistically significant risk factors.

The effects of variables on individual diseases and FM were investigated using multinomial logistic regression analysis. Compared with the "control group with FM", the depression,

\section{Table 1. Criteria for the diagnosis of fibromyalgia}

\section{Criteria}

1. Widespread pain index $\geq 7$ and symptom severity scale score $\geq 5$, or widespread pain index 3-6 and symptom severity scale score $\geq 9$

2. Symptoms present at a similar level for at least 3 months

3. The patient has no disorder that would otherwise explain the pain

\section{Ascertainment}

1. Widespread pain index: Number of areas in which the patient has had pain over the last week (score between 0 and 19) Shoulder girdle, left-right; hip, left-right; jaw, left-right; upper back Upper arm, left-right; upper leg, left-right; chest; lower back Lower arm, left-right; lower leg, left-right; abdomen and neck

2. Symptom severity scale score

Fatigue

Waking unrefreshed

Cognitive symptoms

Somatic symptoms in general anxiety, SF-physical, SF-vitality, SF-mental health, SF-social role, SF-pain and SF-general perceptions scores were statistically significantly increased approximately 2 times, PSQI scores were statistically significantly increased approximately 1.5 times, and anxiety scores were statistically significantly increased approximately 3.5 times in "RLS patients with FM".

Compared with "control group without FM", SF-physical role functioning and SF-emotional role functioning scores were statistically significantly increased approximately 2 times in "control group with FM".

Compared with "control group without FM", PSQI, SFphysical, SF-vitality, SF-social role functioning and SF-pain scores were statistically significantly increased approximately 2 times and anxiety scores were statistically significantly increased approximately 3 times in "RLS patients with FM".

The likelihood of FM among controls was 0.07 and the likelihood of FM among patients was 0.37 . The power of the study was 0.72 with 0.05 error. This power is within acceptable statistical limits.

A statistically significant correlation was found between the RLS Rating Scale and PSQI ( $\mathrm{p}=0.003)$, SF-physical functioning $(\mathrm{p}=0.004)$, SF-emotional $(\mathrm{p}=0.032)$, SF-vitality $(\mathrm{p}=0.032)$, SFmental health $(p=0.011)$, SF-social role functioning $(p=0.011)$, and SF-pain $(\mathrm{p}=0.005)$. There were no statistically significant differences between patients with and without FM in terms of the RLS Rating Scale ( $\mathrm{p}=0.011)$.

\begin{tabular}{|c|c|c|c|c|c|c|}
\hline & & \multicolumn{2}{|c|}{ Patient } & \multicolumn{2}{|c|}{ Control } & $\mathrm{p}$ value \\
\hline \multirow[t]{2}{*}{ Age (years) } & & \multicolumn{2}{|c|}{$44.73 \pm 11.23$} & \multicolumn{2}{|c|}{$46.00 \pm 12.23$} & \multirow{2}{*}{0.680} \\
\hline & & Number & $\%$ & Number & $\%$ & \\
\hline \multirow[t]{2}{*}{ Sex } & Female & 20 & 66.7 & 17 & 56.7 & \multirow{2}{*}{0.430} \\
\hline & Male & 10 & 33.3 & 13 & 43.3 & \\
\hline \multirow[t]{3}{*}{ FM } & Yes & 11 & 36.7 & 2 & 6.7 & \multirow{2}{*}{0.010} \\
\hline & No & 19 & 63.3 & 28 & 93.3 & \\
\hline & & Mean & SD & Mean & SD & \\
\hline PSQI & & 8.73 & 4.48 & 4.77 & 2.49 & $<0.001$ \\
\hline Depression & & 14.03 & 8.22 & 8.13 & 7.95 & 0.004 \\
\hline Anxiety & & 15.97 & 10.43 & 6.57 & 6.56 & $<0.001$ \\
\hline SF-physical functioning & & 62.17 & 26.02 & 86.50 & 17.72 & $<0.001$ \\
\hline SF-physical role functioning & & 77.83 & 36.07 & 89.17 & 26.00 & 0.191 \\
\hline SF-emotional role functioning & & 82.08 & 35.88 & 81.21 & 35.53 & 0.876 \\
\hline SF-vitality & & 42.60 & 16.20 & 57.17 & 17.55 & 0.004 \\
\hline SF-mental health & & 47.77 & 17.73 & 59.20 & 17.43 & 0.023 \\
\hline SF-social role functioning & & 62.08 & 23.78 & 85.42 & 19.44 & $<0.001$ \\
\hline SF-bodily pain & & 53.00 & 27.42 & 77.00 & 24.99 & 0.001 \\
\hline SF-general health perceptions & & 48.68 & 24.71 & 65.00 & 20.47 & 0.013 \\
\hline
\end{tabular}




\section{Discussion}

Spontaneous remission can be observed within one year in patients with mild forms of RLS (60\% of patients) (22). Therefore, patients who present to physicians are patients with moderate to severe symptoms. Although RLS symptoms in more than half $(56.7 \%)$ of the patients in our study were severe, $23.3 \%$ had moderate and $20 \%$ had very severe scores. It is known that the diagnosis of RLS predisposes to depression and anxiety disorders and that they occur more frequently with increased disease severity $(23,24)$. Clinical depression is $2-4$ times more frequent in patients with RLS than in controls (25). This is not an extension of chronic insomnia, it is a comorbidity (26). Sleep-related disorders are present in $43.4 \%$ of patients with RLS (27). Polysomnography studies revealed longer sleep-onset latencies and higher arousal indices in patients with RLS $(6,28)$.

One of the objectives of our study was to examine the effects of RLS on depression, anxiety, and sleep in patients admitted to

\begin{tabular}{|c|c|c|c|}
\hline & & Number & Percentage $(\%)$ \\
\hline \multirow{2}{*}{$\begin{array}{l}\text { Dopamine } \\
\text { agonist }\end{array}$} & Yes & 3 & 10.0 \\
\hline & No & 27 & 90.0 \\
\hline \multirow[t]{4}{*}{ RLS severity } & Mild & 0 & 0.0 \\
\hline & Moderate & 7 & 23.3 \\
\hline & Severe & 17 & 56.7 \\
\hline & Very severe & 6 & 20.0 \\
\hline
\end{tabular}

our clinic. Consistent with previous studies, sleep quality was significantly worse (2 times), and depression (3 times) and anxiety scores (2.5 times) were higher in the patient group. In addition, a significant correlation was observed between the severity of RLS and PSQI scores. This supports that quality of sleep is disrupted with increased severity of the disease.

The main feature of SF-36 is that it is a self-assessment scale. The short completion time and assessment of the positive aspects of health status, as well as the negative aspects are among the advantages of this scale (29). In our study, the physical functioning (difficulty in fulfilling physical activity), vitality (feeling tired and exhausted), mental health (irritability and anxiety), social role functioning (the interruption in normal social activities due to physical and emotional problems), bodily pain and general health perception (belief in having a poor and increasingly worsening health) scores were significantly lower in the patient group. Abetz et al. (30) previously assessed 85 patients with every-night RLS symptoms using SF-36. Although significant decreases were observed in all scales of SF-36, the most worsened was observed in the "vitality" and "physical functioning" subscales (30). In social studies with larger patient groups, the deterioration in physical and emotional role functioning subscales of SF-36 was more than in patients with type2 diabetes mellitus, osteoarthritis, and depression (31). However, although RLS caused mental and physical health deterioration in our study group, it did not cause any limitations. One reason for this situation could also be due to differences in the methodology used in these studies. We obtained information face-to-face with patients admitted to our clinic in our study, whereas Kushida et al. (31) reported that they made phone inquiries for the SF-36.

Physical role functioning, emotional role functioning, vitality, mental health, social role functioning, and bodily pain subscales were affected with increasing severity of RLS. However, it did not cause changes in the physical functioning and general health

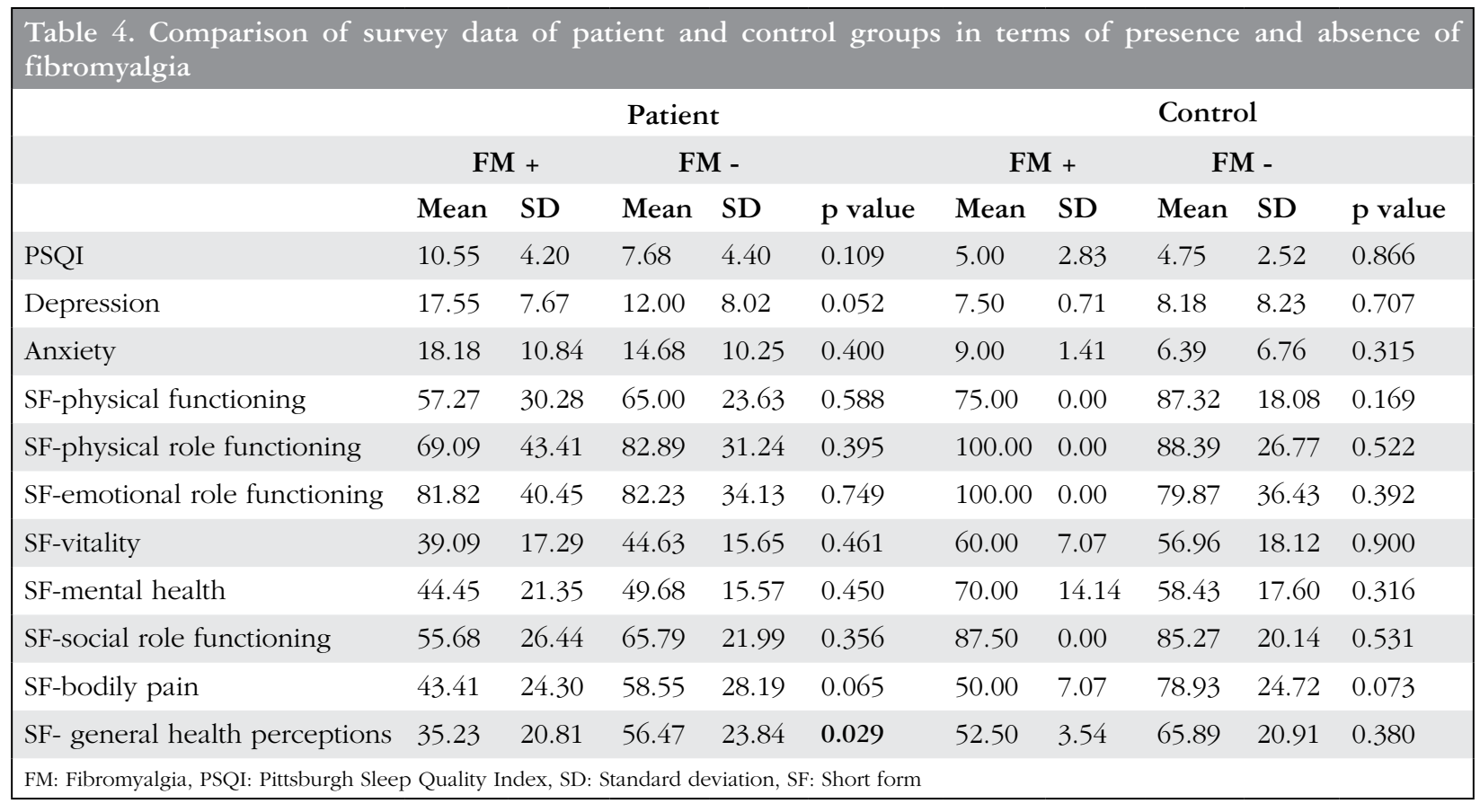


perception subscales. Similarly, in previous studies, increased RLS severity was shown to decrease the quality of life and negatively affect daytime mental and physical activities (32,33).

Dopamine is an important neurotransmitter in neuromodulation of pain. Although the pathogenesis of RLS is not fully understood, a decreased amount of iron in the central nervous system and perturbation in the dopaminergic system were thought to play important roles (34). It is suggested that dopamine activity decreases at night as a result of postsynaptic receptor desensitization due to hyperdopaminergia (35). The use of dopamine- containing drugs in the treatment supports this hypothesis $(36,37)$. In addition, problems in glutamate and opioid systems in the central nervous system and abnormalities in sensory perception in the peripheral nervous system have been suggested in the pathogenesis (34).

The prevalence of RLS in studies in patients with FM was found as $65 \%(9,38)$. Although both diseases are known to be associated, differential diagnosis might be difficult in patients with severe pain in the lower extremities. The majority of patients with FM have moderate or severe RLS (39). However, no difference was detected between patients with RLS (moderate/severe/very severe) with and without FM in terms of the severity of RLS in our study.

Symptom load in RLS is higher in patients with chronic pain (40). Dopamine D2 receptors have been shown to have increased sensitivity and density in patients with FM (41). There is a decrease in presynaptic dopamine activity in positron emission tomography studies (42). As can be seen, dopamine is important in the pathogenesis of both diseases, but the presence of a dysregulation in the central and peripheral pain perception in patients with chronic pain should also be kept in mind (43). The presence of RLS in patients with FM was investigated previously, but the presence of FM has not been studied in patients with RLS. Stehlik et al. (44) reported that the presence of FM in patients with RLS might be lower. In our study, FM prevalence was high in patients with RLS (36.67\%) and was significantly higher (5 times) than that of the control group. This can be explained both by the common neuroendocrine pathogenesis and frequent occurrence of both diseases in the community. However, the lack of additional screening for iron deficiency is a limitation of this study.

Headache, fatigue, sleep disturbances, depression and anxiety are common in patients with FM and/or RLS and quality of life is adversely affected $(10,34,35,45,46)$. Looking at the data from our study, the addition of FM symptoms on RLS symptoms causes significantly worse responses to questions ("How do you think your overall health is?" and "I get ill more easily than other people") about general health only.

In a previously conducted study, worsening was shown in general body perception in patients with FM compared with patients without FM (47). In our study, the presence of FM in patients with FM also had a negative impact, especially on the personal evaluation of their own health. Coexistence of two diseases led to an additional worsening in other scales that measured quality of life.

Sleep disturbances and depression were 2 times and anxiety was 3 times more in the group with concurrent RLS and FM compared with the group without any disease, which was significantly different. In addition, SF-physical, SF-vitality, SF-social and SF-pain scores were 2 times worse. As a result, the coexistence of these two diseases could worsen anxiety symptoms especially, or patients with anxiety might feel the symptoms of these two diseases more severely.

Compared with the group with only FM, depression, anxiety, SFphysical, SF-vitality, SF-mental health, SF-social role functioning, SF-pain and SF-general health perception scales were 2 times worse, and sleep quality was approximately 1.5 times worse, which were significantly different, and anxiety scores were approximately 3.5 times higher in the group with concurrent RLS and FM. However, unlike the RLS patient group, the presence of only FM in the control group without RLS significantly increased SF-physical functioning and SF-emotional role functioning 2 times. Regarding this, the presence of FM affects daily life both physically and emotionally.

\section{Conclusion}

As a result of these findings, FM frequency in patients with moderate and severe RLS symptoms can be suggested to be more $(36.7 \%)$. RLS impairs quality of life. However, the coexistence of FM does not worsen this deterioration. It only worsens the scores of patients' assessments of their own health. The coexistence of two diseases affects the anxiety scores most adversely.

The inclusion of all patients with RLS findings without questioning whether it is primary or secondary is another limitation of our study. The examination of the presence of FM in a greater number of patients with RLS and iron deficiency screening, and investigation of a common pathogenesis should be considered to shed light to the diagnosis and treatment of these two frequent diseases.

\section{Ethics}

Ethics Committee Approval: The study were approved by the İstanbul Medipol University of Local Ethics Committee (protocol number: 10840098-23), Informed Consent: Consent form was filled out by all participants.

Peer-review: Externally peer-reviewed.

\section{Authorship Contributions}

Surgical and Medical Practices: Nesrin Helvaci Yilmaz, Concept: Nesrin Helvacı Yılmaz, Emir Cantürk, Engin Çakar, Fahriye Feriha Özer, Design: Nesrin Helvacı Yılmaz, Lütfü Hanoğlu, Fahriye Feriha Özer, Data Collection or Processing: Nesrin Helvacı Yılmaz, Emir Cantürk, Özge Arıcı Düz, Burcu Polat, Sema Demirci, Ahmet Mithat Tavlı, Didem Taşkın, Ayşe Pınar Doğru, Analysis or Interpretation: Nesrin Helvaci Yilmaz, Özge Arıcı Düz, Bilge Parlakoğlu, Burcu Polat, Literature Search: Nesrin Helvacı Yılmaz, Engin Çakar, Writing: Nesrin Helvacı Yılmaz, Özge Arıc1 Düz, Burcu Polat.

Conflict of Interest: No conflict of interest was declared by the authors.

Financial Disclosure: The authors declared that this study received no financial support.

\section{References}

1. Allen RP, Picchietti DL, Garcia-Borreguero D, Ondo WG, Walters AS, Winkelman JW, Zucconi M, Ferri R, Trenkwalder C, Lee HB, International Restless Legs Syndrome Study G. Restless legs syndrome/Willis-Ekbom disease diagnostic criteria: updated International Restless Legs Syndrome Study Group (IRLSSG) consensus criteria--history, rationale, description, and significance. Sleep Med 2014;15:860-873. 
2. Karroum EG, Golmard JL, Leu-Semenescu S, Arnulf I. Painful restless legs syndrome: a severe, burning form of the disease. Clin J Pain 2015;31:459466.

3. Allen RP, Earley CJ. The role of iron in restless legs syndrome. Mov Disord 2007;22(Suppl 18):S440-448.

4. Edwards RR, Quartana PJ, Allen RP, Greenbaum S, Earley CJ, Smith MT. Alterations in pain responses in treated and untreated patients with restless legs syndrome: associations with sleep disruption. Sleep Med 2011;12:603609.

5. Hoogwout SJ, Paananen MV, Smith AJ, Beales DJ, O'Sullivan PB, Straker LM, Eastwood PR, McArdle N, Champion D. Musculoskeletal pain is associated with restless legs syndrome in young adults. BMC Musculoskelet Disord 2015;16:294.

6. Cho YW, Song ML, Earley CJ, Allen RP. Prevalence and clinical characteristics of patients with restless legs syndrome with painful symptoms. Sleep Med 2015;16:775-778.

7. Winkelman JW, Gagnon A, Clair AG. Sensory symptoms in restless legs syndrome: the enigma of pain. Sleep Med 2013;14:934-942.

8. Yunus MB, Aldag JC. Restless legs syndrome and leg cramps in fibromyalgia syndrome: a controlled study. BMJ 1996;312:1339.

9. Stehlik R, Arvidsson L, Ulfberg J. Restless legs syndrome is common among female patients with fibromyalgia. Eur Neurol 2009;61:107-111.

10. Viola-Saltzman M, Watson NF, Bogart A, Goldberg J, Buchwald D. High prevalence of restless legs syndrome among patients with fibromyalgia: a controlled cross-sectional study. J Clin Sleep Med 2010;6:423-427.

11. Hornyak M, Sohr M, Busse M, Study G. Evaluation of painful sensory symptoms in restless legs syndrome: experience from two clinical trials. Sleep Med 2011;12:186-189.

12. Walters AS, LeBrocq C, Dhar A, Hening W, Rosen R, Allen RP, Trenkwalder C, International Restless Legs Syndrome Study G. Validation of the International Restless Legs Syndrome Study Group rating scale for restless legs syndrome. Sleep Med 2003;4:121-132.

13. Buysse DJ, Reynolds CF, Monk TH, Berman SR, Kupfer DJ. The Pittsburgh Sleep Quality Index: a new instrument for psychiatric practice and research. Psychiatry Res 1989;28:193-213.

14. Beck AT, Steer RA, Brown GK. Manual for Beck Depression Inventory-II. San Antonio, TX: Psychological Corporation. 1996.

15. Beck AT, Epstein N, Brown G, Steer RA. An inventory for measuring clinical anxiety: psychometric properties. J Consult Clin Psychol 1988;56:893-897.

16. Ware JE Jr, Sherbourne CD. The MOS 36-item short-form health survey (SF36). I. Conceptual framework and item selection. Med Care 1992;30:473483

17. Hisli N. Beck Depresyon Envanteri’nin üniversite öğrencileri için geçerliği, güvenirliği. Psikoloji Dergisi 1989;7:3-13.

18. Ulusoy M, Şahin NH, Erkmen H. Turkish version of the Beck Anxiety Inventory: Psychometric properties. J Cogn Psychother 1998;12:163-172.

19. Ağargün MY, Kara H, Anlar Ö. Pittsburgh Uyku Kalitesi İndeksinin Geçerlilik ve Güvenilirliği. Türk Psikiyatri Dergisi 1996;7:107-115.

20. Koçyiğit H, Aydemir Ö, Fişek G, Ölmez N, Memiş A. Kısa Form-36 (KF36)'nın Türkçe versiyonu'nun güvenilirliği ve geçerliliği. İlaç ve Tedavi Dergisi 1999;12:102-106.

21. Wolfe F, Clauw DJ, Fitzcharles MA, Goldenberg DL, Katz RS, Mease P, Russell AS, Russell IJ, Winfield JB, Yunus MB. The American College of Rheumatology preliminary diagnostic criteria for fibromyalgia and measurement of symptom severity. Arthritis Care Res (Hoboken) 2010;62:600-610.

22. Lee CS, Kim T, Lee S, Jeon HJ, Bang YR, Yoon IY. Symptom Severity of Restless Legs Syndrome Predicts Its Clinical Course. Am J Med 2016;129:438-445.

23. Winkelmann J, Prager M, Lieb R, Pfister H, Spiegel B, Wittchen HU, Holsboer F, Trenkwalder C, Strohle A. "Anxietas tibiarum". Depression and anxiety disorders in patients with restless legs syndrome. J Neurol 2005;252:67-71.
24. Sevim S, Dogu O, Kaleagasi H, Aral M, Metin O, Camdeviren H. Correlation of anxiety and depression symptoms in patients with restless legs syndrome: a population based survey. J Neurol Neurosurg Psychiatry 2004;75:226-230.

25. Hornyak M. Depressive disorders in restless legs syndrome: epidemiology, pathophysiology and management. CNS Drugs 2010;24:89-98.

26. Gupta R, Lahan V, Goel D. A study examining depression in restless legs syndrome. Asian J Psychiatr 2013;6:308-312.

27. Hening W, Walters AS, Allen RP, Montplaisir J, Myers A, Ferini-Strambi L. Impact, diagnosis and treatment of restless legs syndrome (RLS) in a primary care population: the REST (RLS epidemiology, symptoms, and treatment) primary care study. Sleep Med 2004;5:237-246.

28. Winkelman JW, Redline S, Baldwin CM, Resnick HE, Newman AB, Gottlieb DJ. Polysomnographic and health-related quality of life correlates of restless legs syndrome in the Sleep Heart Health Study. Sleep 2009;32:772-778.

29. Carr AJ, Thompson PW, Kirwan JR. Quality of life measures. Br J Rheumatol 1996;35:275-281.

30. Abetz L, Allen R, Follet A, Washburn T, Earley C, Kirsch J, Knight H. Evaluating the quality of life of patients with restless legs syndrome. Clin Ther 2004;26:925-935.

31. Kushida C, Martin M, Nikam P, Blaisdell B, Wallenstein G, Ferini-Strambi L, Ware JE, Jr. Burden of restless legs syndrome on health-related quality of life. Qual Life Res 2007;16:617-624.

32. Durgin T, Witt EA, Fishman J. The Humanistic and Economic Burden of Restless Legs Syndrome. PLoS One 2015;10:e0140632.

33. Svetel MV, Jovic JS, Pekmezovic TD, Kostic VS. Quality of life in patients with primary restless leg syndrome: community-based study. Neurol Sci 2015;36:1345-1351.

34. Ondo WG. Restless legs syndrome: pathophysiology and treatment. Curr Treat Options Neurol 2014;16:317.

35. Jones R, Cavanna AE. The neurobiology and treatment of restless legs syndrome. Behav Neurol 2013;26:283-292.

36. Akpinar S. Treatment of restless legs syndrome with levodopa plus benserazide. Arch Neurol 1982;39:739.

37. Akpinar S. Restless legs syndrome treatment with dopaminergic drugs. Clin Neuropharmacol 1987;10:69-79.

38. Zoppi M, Maresca M. Symptoms accompanying fibromyalgia. Reumatismo 2008;60:217-220

39. Civelek GM, Ciftkaya PO, Karatas M. Evaluation of restless legs syndrome in fibromyalgia syndrome: an analysis of quality of sleep and life. J Back Musculoskelet Rehabil 2014;27:537-544.

40. Stehlik R, Ulfberg J, Hedner J, Grote L. High prevalence of restless legs syndrome among women with multi-site pain: a population-based study in Dalarna, Sweden. Eur J Pain 2014;18:1402-1409.

41. Malt EA, Olafsson S, Aakvaag A, Lund A, Ursin H. Altered dopamine D2 receptor function in fibromyalgia patients: a neuroendocrine study with buspirone in women with fibromyalgia compared to female population based controls. J Affect Disord 2003;75:77-82.

42. Wood PB, Patterson JC, Sunderland JJ, Tainter KH, Glabus MF, Lilien DL. Reduced presynaptic dopamine activity in fibromyalgia syndrome demonstrated with positron emission tomography: a pilot study. J Pain 2007;8:51-58.

43. Sarzi-Puttini P, Atzeni F, Mease PJ. Chronic widespread pain: from peripheral to central evolution. Best Pract Res Clin Rheumatol 2011;25:133-139.

44. Stehlik R, Arvidsson L, Ulfberg J. Restless legs syndrome is common among female patients with fibromyalgia. Eur Neurol 2009;61:107-111.

45. Becker PM. The biopsychosocial effects of restless legs syndrome (RLS). Neuropsychiatr Dis Treat 2006;2:505-512.

46. Becker PM, Novak M. Diagnosis, comorbidities, and management of restless legs syndrome. Curr Med Res Opin 2014;30:1441-1460.

47. Akkaya N, Akkaya S, Atalay NS, Balci CS, Sahin F. Relationship between the body image and level of pain, functional status, severity of depression, and quality of life in patients with fibromyalgia syndrome. Clin Rheumatol 2012;31:983-988. 